KAMIL STOLARSKI

\title{
Justa causa usucapionis w poglądach Trebacjusza i Fragmentach Watykańskich ${ }^{1}$
}

\begin{abstract}
Justa causa usucapionis according to Trebatius and the Vatican Fragments

The author of the paper discusses the construct of usucaption as approached by Trebatius and Fragmentum Vaticanum 1 in the context of just cause of usucaption (iusta causa usucapionis). In the sources analyzed in the text, one may find the oldest preserved mentions concerning the prerequisite for usucapio, which, according to the author, is an important element of that legal construct. The article presents the following fragments: D. 41,4,2,7; D. 41,6,4, D. 41,10,4 pr. and Fragmentum Vaticanum 1, giving much thought to the latter - particularly focusing on Labeo's notion incorporated in the source. His standpoint, included in Fragmentum Vaticanum 1, was presented together with the opinions of earlier (veteres) and later (Sabinus, Cassius, Proculus, Celsus, Julian, and Paul) jurists. The texts indicate that at the turn of the republic and the Principate, usucaption was a well-formed institution, for which the reasonable cause of usucaption was an important premise. The lawyers of those times focused on the analyses of cases which today we would think of as the most difficult ones.
\end{abstract}

Keywords: usucaption, reasonable cause of usucaption, Trebatius, Vatican Fragments, Roman law

Słowa kluczowe: zasiedzenie, uzasadniona przyczyna zasiedzenia, Trebacjusz, Fragmenty Watykańskie, prawo rzymskie

Korzeni rzymskiej koncepcji zasiedzenia można się doszukiwać już w ustawie XII Tablic ${ }^{2}$, aczkolwiek niemożliwe jest opisanie prawa tamtego okresu za pomocą pojęć

1 Projekt został sfinansowany ze środków Narodowego Centrum Nauki przyznanych na podstawie decyzji numer DEC-2013/11/N/HS5/04217.

2 Aczkolwiek nie jest to pewne, toczy się tutaj wciąż ożywiona dyskusja, por. m.in.: G. Nicosia, Iuris consultorum acutae ineptiae [w:] Studi di onore di Remo Martini, II, Milano 2009, s. 865; T. Giaro, Własność w Rzymie republikańskim, CPH, 1973, t. 25, z. 2, s. 239; W. Dajczak, T, Giaro, F. Longchamps de Bérier, Prawo rzymskie. U podstaw prawa prywatnego, Warszawa 2009, s. 385; B. Albanese, Usus auctoritas fundi in XII Tab. 6,3 secondo le testimonianze di Cicerone, AUPA, 1998, t. XLV.1, s. 27, passim; J. Casiono-Mora, Auctoritas rerum decemviralis, RIDA, 3 e Série, 2003, t. 50, s. 47-96; podobnie A.J.B. Sirks, An Aspect of 
powstałych zdecydowanie później ${ }^{3}$. W zachowanych do naszych czasów poglądach veteres także można znaleźć te dotyczące usucapio ${ }^{4}$. Jednak dopiero czytając fragmenty wyjęte z dzieł Trebacjusza i kolejnych prawników, odnajdujemy dogmatyczne ujęcie zasiedzenia. Stanowi ono w zasadzie pierwszą pełną konceptualizację tej konstrukcji, która do dziś funkcjonuje w porządkach prawnych ukształtowanych przez tradycję prawną ius civile. Co ciekawe, w zasadzie od razu widzimy usucapio opartą na przesłankach znanych do dziś, ujętych później w heksametr składający się ze słów: res habilis, titulus, fides, possessio, tempus ${ }^{5}$. Już juryści działający na przełomie republiki i pryncypatu doskonale rozumieli pojęcie podstawy zasiedzenia, określanej później jako iusta causa usucapionis lub titulus - co zdaje się wynikać z analizy przedstawionych w dalszej części artykułu źródeł. Dlatego też badania historyczno-prawne mające na celu analizę tej przesłanki usucapio powinny objąć dzieła prawników wczesnoklasycznych. Poczynając od Trebacjusza i pierwszego z przekazanych nam we Fragmentach Watykańskich źródła - zawierającego co prawda odniesienie do prawników działających w latach trochę późniejszych, takich jak Sabinus, Kasjusz, Proculua, Celsua czy wreszcie Paulus i Julian oraz przede wszystkim przywołującego pogląd współczesnego Trebacjuszowi Labeona.

\section{Trebacjusz}

\section{D. $41,4,2,7$}

Gaiusz Trebacjusz Testa był jednym z prawników, którzy urodzeni jeszcze w czasach republiki rzymskiej, część swojego życia spędzili już w nowym ustroju - ustrój ten zresztą Trebacjusz współtworzył ${ }^{6}$. Urodził się w połowie lat osiemdziesiątych I w. przed Chr., zmarł krótko po 4 r. po Chr. ${ }^{7}$ Cieszył się ogromnym poważaniem u jurystów klasycznych i był przez nich dość często cytowany ${ }^{8}$. Dzięki temu do naszych czasów przetrwały liczne jego uwagi - również te, które dotyczyły causa usucapionis. Omawiając je, zacznijmy od krótkiego tekstu pochodzącego z pism Paulusa:

D. 41,4,2,7 (Paulus libro 54 ad edictum): Eius bona emisti, apud quem mancipia deposita erant: Trebatium ait usu te non capturum, quia empta non sint.

Archaic Roman Law: Auctoritas Tutoris [w:] The Law's Beginnings, red. F.J.M. Feldbrugge, Leiden-Boston 2003, s. 58; P. Fuenteseca, La auctoritas como principio constutucional romano [w:] Libro homenaje al profesor Manuel Albaladejo Garcỉa, t. I, red. J.M. González Porrad, F.P. Méndzez González, Murcia 2004, s. 1767-1774; M. Lauria, ... usus auctoritas fundi biennium est ... [w:] De iustitia et iure: Festgabe für Ulrich von Lübtow zum 80. Geburstag, red. M. Harder, G. Thielmann, Berlin 1980, s. 163-185.

3 E.J.H. Schrage, res habilis, titulus, fides, possessio, tempus. A Medieval Mnemonic Hexameter? [w:] F. Sturm, P. Thomas, J. Otto, Liber Amicorum Guido Tsuno, Frankfurt am Main 2013, s. 325.

4 M.in.: D. 41,2,3,19; D. 41,2,3,23.

5 Por: E.J.H. Schrage, res habilis, titulus..., passim.

${ }^{6}$ Y. Benferhat, Cicero's Law. Rethinking Roman Law of the Late Republic, ed. P. du Plessis, Edinburgh 2016, s. 81.

7 W. Litewski, Jurysprudencja rzymska, Kraków 2000, s. 152.

8 Ibidem. 
Kupiłeś dobra tego, u którego niewolnicy byli zdeponowani: Trebacjusz twierdzi, że nie zasiedzisz, ponieważ nie byli kupieni.

Tekst ten nie był, jak się wydaje, podejrzany dotychczas o interpolacje ${ }^{9}$. Jego treść zdołamy zrozumieć tylko wtedy, gdy zwrócimy uwagę na poprzedzający go passus D. 41,4,2,6. Przed przejściem do kwestii zdeponowanych niewolników Paulus najpierw przedstawia w nim przypadek, w którym ktoś wszedł w posiadanie innego niewolnika, niż wynikało to z umowy kupna-sprzedaży:

D. 41,4,2,6 (Paulus libro 54 ad edictum): Cum Stichum emissem, Dama per ignorantiam mihi pro eo traditus est. Priscus ait usu me eum non capturum, quia id, quod emptum non sit, pro emptore usucapi non potest $[\ldots]$.

Gdy kupiłem Stichusa, zamiast niego wydany mi został Dama przy mej nieświadomości. Prisus stwierdził, że nie zasiedzę tego, ponieważ to, co nie byłoby kupione, nie może zostać zasiedziane pro emptore $[\ldots]$.

Następnie Paulus opisuje sytuację, w której podmiot uzyskał władztwo faktyczne nad nieruchomością w szerszym zakresie, niż wynikało to z tego kontraktu.

D. 41,4,2,6 (Paulus libro 54 ad edictum): [...] sed si fundi emptus sit et ampliores fines possessi sint, totum longo tempore capi, quoniam univeritas eius possideatur non singulae partes.

[...] ale jeżeli zostałby kupiony grunt i byłby posiadany w większych granicach, cały nabędę wskutek upływu długiego czasu, ponieważ całość jego posiada się, a nie pojedyncze części.

Oba podane przez późnoklasycznego jurystę przykłady dotyczą zagadnienia rozmijania się przedmiotu possessio z przedmiotem emptio-venditio. Jeżeli założymy, że również kolejny fragment wypowiedzi Paulusa - D. 41,4,2,7 - osadzony jest w tym kontekście, okaże się on w pełni zrozumiały. Użyty w nim termin bona najwyraźniej oznacza dobra sprzedającego, tj. jego wydzieloną część albo wręcz całość należącego do niego majątku ${ }^{10}$. W owych bona, które były przedmiotem emptio-venditio, faktycznie znajdowali się niewolnicy, jednak w sensie prawnym byli oni jedynie zdeponowani u sprzedawcy. Miał on zatem jedynie corpus, a dzierżył ich dla, i w imieniu, deponenta. Natomiast nabywca wszedł w ich posiadanie razem z całością dóbr. Najwyraźniej zyskał jedynie detentio niewolników i taką sytuacją zajął się Trebacjusz. Uznał, że nie doszło do zasiedzenia, ponieważ niewolników tych nie dotyczył kontrakt kupna-sprzedaży. Nie byli oni bowiem wydzieloną częścią sprzedawanych dóbr. Co ciekawe, jako przyczyny nie podał on faktu uzyskania władztwa nad rzeczą od osoby nieuprawnionej, ale wejście w posiadanie bez podstawy ku temu w postaci emptio-venditio. Tak tedy widział przekazanie przez depozytariusza jedynie corpus i nie sugerował, że doszło samowolnie do zmiany przyczyny posiadania - co byłoby niedozwolone według oczywistej już dla veteres zasady nemo sibi ipse causam possessionis mutare potest ${ }^{11}$. Opisywał sytuację

9 E. Levy, E. Rabel, Index Interpolationum quae in Iustiniani digesits inesse dicuntur, ad D. 41,4,2,7.

10 A. Watson, The Law of Property in the Later Roman Republic, Oxford 1968, s. 54. Odnośnie do pojęcia bona w tym znaczeniu zob. H. Ankum, E. Pool, The Development of Roman Double Ownership [w:] New Perspective in the Roman Law of Property, red. P. Birks, Oxford 1999, s. 9-14.

11 Por. m.in.: R. Böhr, Das Verbot der Eigenmächtigen Besitzumwandlung im Römischen Privatrecht. Ein Beitrag zur Rechtshistorischen Spruchregelforschung, München-Leipzig 2015, s. 70, passim; H. Haus- 
faktyczną i prawną na podstawie zawartych umów - chyba z przekonaniem, że nie doszło do niczego nieuczciwego.

Wszelako warto się zastanowić, co zdecydowałby Trebacjusz Testa, gdyby przedmiotem umowy nie były bona, ale ci konkretni niewolnicy. Wtedy bowiem rozstrzygnięcie mogłoby kształtować się zgoła odmiennie. Jest przecież wysoce prawdopodobne, że w takim stanie faktycznym nabywający był przekonany, iż niewolnicy stanowili część otrzymanego przez niego majątku. $Z$ analizowanego tekstu wynika, że Trebacjusz bardzo ściśle wiązał przedmiot posiadania z przedmiotem emptio-venditio, a więc czynności, która miała być podstawą faktycznego przysporzenia. O ile przedmiot possessio określany był w prawie rzymskim na podstawie tego, nad czym podmiot sprawował władzę faktycznie, o tyle przedmiot kupna-sprzedaży Trebacjusz bezwzględnie określa przez wyłożenie normatywnej treści zawartej umowy. Przedmiot władztwa faktycznego musiał więc, w jego mniemaniu, odpowiadać treści stosunku prawnego, jeżeli zawiązanie tego stosunku miało być podstawą posiadania rzeczy, a w konsekwencji - jej zasiedzenia. Podsumowując ustalenia na podstawie fragmentu D. 41,4,2,7, należy uznać, że w przytoczonym przez Paulusa, a wcześniej Trebacjusza, przykładzie brak causa usucapionis przejawia się w tym, że podmiot uzyskał władztwo faktyczne nad rzeczami, które nie były objęte umową kupna-sprzedaży. Do wejścia w possessio nie doszło bowiem w wyniku umowy kupna-sprzedaży. Wszystko to wykluczało, w przekonaniu Trebacjusza, zasiedzenie z uwagi na brak dla niego podstawy, causae.

\section{D. $41,6,3$}

Poddajmy teraz analizie kolejny tekst, w którym przedstawiono poglądy Trebacjusza na interesujące nas kwestie. Tym razem pochodzi on z komentarza Pomponiusza do pism Kwintusa Mucjusza Scewoli:

D. 41,6,3 (Pomponius libro 24 ad Quintum Mucium): Si vir uxori vel uxor viro donaverit, si aliena res donata fuerit, verum est, quod Trebatius putabat, si pauperior is qui donasset non fieret, usucapionem possidenti procedere.

Jeżeli mąż żonie albo żona mężowi daruje, gdy darowana byłaby cudza rzecz, prawdą jest, co Trebacjusz sądził, że ma miejsce zasiedzenie przez posiadającego, jeżeli nie stałby się uboższy ten, który darowałby.

Również ten fragment nie jest podejrzewany o interpolacje ${ }^{12}$. Jak wiemy, w prawie rzymskim darowizna między małżonkami była zakazana ${ }^{13}$. Rzymskie małżeństwo nie miało bowiem pociągać za sobą skutków w sferze majątkowej ${ }^{14}$. Ograniczenie to nie

maninger, Nemo sibi ipse causam possessionis mutare potest - eine Regel der veteres in der Diskussion der Klassiker [w:] Aktuelle Fragen aus modern Recht und Rechtsgeschichte. Gedächtnisschrift für Rudolf Schmidt, red. E. Seidl, Berlin 1966, passim; T. Giaro, Diritto come prassi. Vicende del discorso giurisprudenziale [w:] Fides, humanitas, ius. Studi in onore di Luigi La bruna, vol. IV, Napoli 2007, s. 2255; G. Maccormack, Nemo sibi ipse causam possessionis mutare potest, BIDR, 3 serie, 1972, t. 14, s. 71.

12 E. Levy, E. Rabel, Index Interpolationum ..., ad D. 41,6,3.

13 D. Johnston, Roman Law in Context, Cambridge 2007, s. 34.

14 Ibidem.

Artykuły - Articles 
wydawało się obowiązywać bezwzględnie. W źródłach zauważa się jako jedną z ratio zakazu „uniemożliwienie wzbogacenia” się jednego małżonka kosztem drugiego ${ }^{15}$. Jeśli więc donatio takiego skutku nie wywierała, darowizna była dopuszczalna. Sytuacje takie musiały zresztą być wyjątkowe, ponieważ z samej istotny darowizny wynika wzbogacenie obdarowanego kosztem darczyńcy. W szczególności warto zwrócić uwagę na wypowiedź Terencjusza Klemensa:

D. 24,1,25 (Clementius libro 5 ad legem Iuliam et Papiam): Sed et si constante matrimonio res aliena uxori a marito donata fuerit, dicendum est confestim ad usucapionem eius uxorem admitti, quia et si non mortis causa donaverat ei, non impediretur usucapio. Nam ius constitutum ad eas donationes pertinet, ex quibus et locupletior mulier et pauperior maritus in suis rebus fit: itaque licet mortis causa donatio interveniat, quasi inter extraneas personas fieri intellegenda est in ea re, quae quia aliena est usucapi potest.

Jeżeli w trakcie trwania małżeństwa rzecz cudzą żona od męża w darowiźnie dostanie, należy powiedzieć, że natychmiast dopuszcza się zasiedzenie tej rzeczy przez żonę, gdyż nawet jeśli darował jej nie mortis causa, zasiedzenie nie jest niemożliwe. Ponieważ prawo istniejące dotyczy tych darowizn, w których i żona byłaby bogatsza, a mąż uboższy w swoich rzeczach: i tak jak może mieć miejsce darowizna mortis causa, tak należy sądzić, że jakby miała miejsce [darowizna] pomiędzy innymi osobami w przypadku tej rzeczy, która ponieważ jest obcego, może być zasiedziana.

Terencjusz Klemens, twierdząc, że ,istniejące prawo dotyczy tych darowizn, w których żona byłaby bogatsza, a mąż uboższy”, wypowiada się o zakresie stosowania normy zakazującej donatio inter virum et uxorem. Wynika z tego, że ta reguła nie ma zastosowania wtedy, gdy nie dochodzi do zmiany w majątku obu małżonków, korzystnej dla jednego z nich i niekorzystnej dla drugiego ${ }^{16}$. Z taką zaś sytuacją mamy do czynienia wtedy, gdy przedmiotem darowizny jest rzecz cudza. Tym samym darowizna dokonana pomiędzy małżonkami, której przedmiotem była taka rzecz, byłaby dopuszczalna i pozwalała na późniejsze nabycie własności wskutek zasiedzenia. Ciekawe w wypowiedzi Terencjusza Klemensa zdaje się stwierdzenie, zgodnie z którym w omawianej sytuacji dochodzi do darowizny quasi inter extraneas personas, skoro następuje zubożenie w majątku innej osoby niż żona ${ }^{17}$.

Wróćmy teraz do wypowiedzi Trebacjusza. W zasadzie stan faktyczny, jaki rozstrzygał, jest tożsamy z tym, który był przedmiotem analizy Terencjusza Klemensa. Mało tego, sam Trebacjusz, uzasadniając dopuszczalność zasiedzenia, stwierdza, że nie doszło do zubożenia tej osoby, która darowała: męża albo żony. Na marginesie zauważmy, że z wypowiedzi obu prawników - ale nie tylko z ich uwag ${ }^{18}$ - wynika, iż dla oceny dopuszczalności tego rodzaju darowizny prawnicy dość powszechnie posługiwali się kryterium wzbogacenia.

Po analizie rozstrzygnięcia Trebacjusza narzucają się następujące wnioski. Nie dopuszczał on zasiedzenia rzeczy wtedy, gdy miała miejsce zakazana prawem darowizna.

15 D. $24,1,1$; D. $24,1,2$; D. $24,1,3$.

16 Por. R. Zimmermann, The Law of Obligations. Roman Foundations of the Civilian Traditions, Cape Town-Wetton-Johannesburg 1992, s. 486, 896-897.

17 Por. F.J. Andrés Santos, En torno al origen y fundamento de la prohibición de donaciones entre cónyuges: una reconsidereción critica, „Bullettino dell'Istituto di Diritto Romano 'Vittorio Scialoja', 3 serie”, 2000-2001, t. 42-43, s. 341.

18 Por. m.in.: D. $24,1,5,16$ i D. $24,1,5,17$. 
Wymogiem więc dopuszczalności usucapio było traditio rzeczy na podstawie ważnego prawnie donatio. W przedstawionym powyżej źródle mamy do czynienia z nabyciem własności poprzez zasiedzenie przez osobę, która uzyskała posiadanie od niewłaściciela. Ciekawe, że w tych akurat okolicznościach faktycznych umożliwiło to usucapio - gdyby mąż był właścicielem darowanej rzeczy, do zasiedzenia by nie doszło. Jak widać, ocena tego, czy spełniona została przesłanka słusznej przyczyny, przebiegała po linii ustalenia, czy miała miejsce ważna z punktu widzenia prawa czynność, na podstawie której doszło do wejścia w posiadanie rzeczy.

\section{D. $41,10,4 \mathrm{pr}$.}

Ostatnie źródło zawierające wypowiedź Trebacjusza w kontekście słusznej podstawy zasiedzenia warto omówić chociażby z uwagi na to, gdzie umieścili ten fragment kompilatorzy. Znalazł się on bowiem w rozdziale 10 księgi 41 Digestów, w którym znajdują się teksty dotyczące tytułu zasiedzenia określonego mianem pro suo.

D. 41,10,4 pr. (Pomponius libro 32 ad Sabinum): pr. Si ancillam furtivam emisti fide bona ex ea natum et apud te conceptum est ita possedisti, ut intra constitutum usucapioni tempus cognosceres matrem eius furtivam esse, Trebatius omni modo, quod ita possessum esset, usucaptum esse. Ego sic puto distinguendum, ut, si nescieris intra statutum tempus, cuius id mancipium esset, aut si scieris neque potueris certiorem dominum facere, aut si potueris quoque et feceris certiorem, usucaperes: sin vero, cum scires et posses, non feceris certiorem, contra esse: tum enim clam possedisse videberis, neque idem et pro suo et clam possidere potest.

Jeśli skradzioną niewolnicę kupiłeś w dobrej wierze i w ten sposób posiadałeś od jej urodzenia, a u ciebie była poczęta, gdy w trakcie określonego czasu zasiedzenia dowiedziałeś się, że matka była skradziona, Trebacjusz w każdym przypadku twierdzi, że jeśli była posiadana, została zasiedziana. Ja wszelako uważam, że należy rozróżnić, czy nie wiedziałeś podczas prawem ustanowionego czasu, czyja ta niewolnica jest, albo wiedziałeś i nie mogłeś powiadomić właściciela, albo również jeśli mogłeś i dokonałeś powiadomienia, zasiedziałeś. Jeśli zaś rzeczywiście, gdy wiedziałeś i mogłeś, nie dokonałeś powiadomienia, wniosek jest odwrotny: wtedy powinieneś uważać, że posiadasz potajemnie, a nie może ten sam posiadać pro suo i potajemnie.

W piśmiennictwie wskazuje się, że tekst ten wymaga uzupełnienia w dwóch miejscach: przed zwrotem ex ea natum przez dodanie quodque, po Trebatius przez dopisanie respondit ${ }^{19}$. Istotniejsze jednak jest to, czy Pomponiusz rzeczywiście powołał się w oryginalnym tekście na poglądy Trebacjusza. W analizowanym przez Salvatore Riccobono ${ }^{20}$ średniowiecznym greckim skrócie, bazującym na Ecloga i innych pracach - Hexabilbos z 1345 r. autorstwa sędziego znanego jako Konstantyn Harmenopulos ${ }^{21}$ - widnieje Neratiusz w tym miejscu, w którym w powyższym przywołaniu źródła występuje Trebacjusz $^{22}$. Zdaniem S. Riccobono należy dać pierwszeństwo tekstowi Harmenopulosa

19 A. Abramenko, Eine übersehene Stellungnahme des Trebatius zum Eigentumerwerb am partus ancillae furtivae. Zu Pomp. D. 41,10,4 pr. und Ulp. D. 6,2,11,2, ZRG RA, 1997, t. 114, s. 426.

20 Por. A. Guarino, Pagine di diritto romano, t. II, Napoli 1993, s. 48.

21 A. Watson, Roman Law and Comparative Law, Georgia 1991, s. 87-88.

22 S. Riccobono, Sul Fr. 4 Pr. D. Pro Suo e la vesione greca riportata da Armenopulo [w:] S. Riccobono, Stritti di diritto romano, t. I, Palermo 1957, s. 339. 
i przyjąć, że Pomponiusz przywołał w swoim tekście poglądy Neracjusza ${ }^{23}$. Niemniej zarówno Alan Watson, jak i Andrik Abramenko - autor szerszej analizy przedmiotowego fragmentu - uważają, że powołanie się przez Pomponiusza na Trebacjusza raczej nie budzi wątpliwości ${ }^{24}$, a zastąpienie w tekście Trebacjusza Neracjuszem jest jednym z wielu błędów pisarskich ${ }^{25}$. W literaturze wskazuje się nadto na dwie inne interpolacje: dodanie słów quodque i constitutum usucapioni tempus ${ }^{26}$. W pozostałym zakresie tekst wydaje się oryginalny. Przy czym zdaniem Pasquale Voci nie ma znaczenia, czy fragment ten jest interpolowany, gdyż co do zasady jest zrozumiały ${ }^{27}$ - z czym należy się zgodzić, biorąc pod uwagę charakter tych zmian.

Dzięki Pomponiuszowi możemy zapoznać się ze stanowiskiem Trebacjusza, zgodnie $\mathrm{z}$ którym w przypadku nabycia $\mathrm{w}$ dobrej wierze niewolnicy i następnie urodzenia się z niej dziecka nabywający mógł uzyskać własność dziecka przez zasiedzenie także wtedy, gdy w trakcie okresu zasiedzenia dowiedział się, że jego matka została skradziona. Alan Watson słusznie zwraca uwagę na to, że stanowisko Trebacjusza jest tutaj absolutne, co zostało wyrażone w tekście sformułowaniem omni modo ${ }^{28}$. Niejako w kontrze do tego Pomponiusz wskazuje, że tylko w niektórych przypadkach pogląd jego poprzednika można uznać za słuszny - co wyraża słowami ego sic putto distinguendum.

Dla pełnego zrozumienia stanowiska Trebacjusza, bo ono nas w tym miejscu interesuje ze względu na prowadzone wcześniej analizy, zwróćmy uwagę na następującą kwestię. Prawo rzymskie przewidywało zakaz nabycia przez zasiedzenie rzeczy skradzionej i zasiedzenia partus ancillae ${ }^{29}$. Usucapio nie mogła obejmować rzeczy skradzionych zapewne już na gruncie ustawy XII Tablic i z całą pewnością po uchwaleniu Lex Atinia ${ }^{30}$. Restrykcja ta była więc na pewno faktem w czasach Trebacjusza. Dlatego właśnie jurysta postanowił rozwiązać problem, którego bez tego ograniczenia by nie było. Matka bowiem nie mogła zostać zasiedziana przez nabywcę, nawet w dobrej wierze, gdyż była res furtiva $^{31}$. To, że dla Trebacjusza niewolnik będący rzeczą skradzioną bezwzględnie nie mógł zostać zasiedziany, wynika z tekstu D. 49,15,27, nawiązującego do prac Labeona.

D. 49.15 .27 (Iavolenus libro 9 ex posterioribus Labeonis): Latrones tibi servum eripuerant: postea is servus ad Germanos pervenerat: inde in bello victis Germanis servus venierat. Negant posse usucapi eum ab emptore Labeo Ofilius Trebatius, quia verum esset eum subreptum esse, nec quod hostium fuisset aut postliminio redisset, ei rei impedimento esse.

Żołnierze najemni uprowadzili tobie niewolnika. Potem ten niewolnik dostał się do Germanów. Stamtąd w trakcie wojny przybył wraz z pokonanymi Germanami. Labeon, Ofiliusz i Trebaciusz zaprzeczyli możliwości zasiedzenia tego niewolnika przez kupującego, ponieważ prawdą jest, że jest skradziony, i nic nie zmieni to, że był u wrogów i zwrócony został z powrotem, co nie jest przeszkodą w sprawie.

23 Ibidem, s. 340.

24 A. Watson, The Law of Property..., s. 29; A. Abramenko, Eine übersehene Stellungnahme des Trebatius..., s. 428.

25 A. Watson, The Law of Property..., s. 29.

26 Ibidem.

27 P. Voci, Modi di acquisto della proprietà, Milano 1952, s. 192.

28 Ibidem, s. 30.

29 Por. M. Kaser, Partus ancillae, ZRG RA, 1958, t. 88, s. 165-176.

30 Por. E. Herrmann-Otto, Ex ancilla natus, Sttuttgart 1994, s. 276-277.

31 G. 2,45 . 
Zakaz ten, zdaniem Trebacjusza, nie rozciągał się już na narodzonego z niej niewolnika, który mógł zostać zasiedziany, jeśli nabywca go posiadał. Nawet wtedy, gdy wiedział już wówczas o tym, że niewolnica była rzeczą skradzioną. Zagadnienie nabycia przez zasiedzenie dziecka skradzionej niewolnicy stało się tematem spornym wśród rzymskich jurystów i często omawianym, co znajduje wyraz w zachowanych do dziś tekstach $^{32}$. Fragment D. 41,10,4 pr. świadczy o tym, że Trebacjusz jako jeden z pierwszych zajął w tej kwestii stanowisko. Co istotne, znaczenie dla niego miała kategoria dobrej wiary. Pozostaje pytanie, czy po analizie tego źródła można cokolwiek powiedzieć o stanowisku Trebacjusza względem iusta causa usucapionis. Tutaj odpowiedź musi być negatywna. Jurysta poza stwierdzeniem dopuszczalności zasiedzenia i podkreśleniem znaczenia dobrej wiary kupującego nie wypowiada się w kwestii tytułu zasiedzenia. Czyni to cytujący go Pomponiusz, używając sformułowania possidere pro suo. Dlatego właśnie kompilatorzy justyniańscy umieścili przedmiotowy fragment w księdze 41, rozdziale 10 Digestów, zatytułowanym właśnie Pro suo, a więc poświęconym tytułowi pro suo, który - wydaje się - mógł stanowić podstawę zasiedzenia, aczkolwiek sporne jest, czy dopuszczali go już prawnicy klasyczni (i być może wcześniejsi), czy też dopiero redaktorzy kompilacji justyniańskiej ${ }^{33}$.

\section{Labeon we Fragmentach Watykańskich 1}

\section{Źródło}

Wypowiedzi Trebacjusza można traktować jako swoiste wprowadzenie do tematyki słusznej przyczyny zasiedzenia - zwięzłe, raczej zrozumiałe, aczkolwiek niemówiące nam o przesłance słusznej przyczyny zasiedzenia zbyt wiele. Inaczej sprawa ma się z zamieszczonym we Fragmentach Watykańskich tekstem Paulusa ${ }^{34}$, wyjętym z księgi ósmej „Komentarza do edyktu” ${ }^{35}$. O autorstwie Paulusa świadczy podobieństwo do koń-

32 P. Bělovský, Usucapio of Stolen Things and Slave Children, „Revue internationale des sciences sociales" 2002, vol. 49, passim.

33 Por. m.in: L. Winkel, Usucapio pro suo and the Classification of the causae usucapionis by the Roman Jurists [w:] New Perspectives..., passim; E. Albertario, Studi di diritto romano, vol. 2: Cose - diritti reali possesso, Milano 1941, s. 192; Th. Mayer-Maly, Das Intativtitelproblem bei der Usucapio,. Graz-Köln 1962, , s. 47; P. Bonfante, Le singole 'iustae causae usucapionis'e il titolo putativo [w:] P. Bonfante, Scritti giuridici varii..., vol. 2, passim.

34 Por. D. 18,1,27; A.A. Buchholtz, Excursus I. De Fontibus Vaticanorum Fragmentorum [w:] Iuris civilis anteiustinianei vaticana fragmento e codice rescripto ab Angelo Maio edita recognovit, commentario tum critic tum exegetico nec non quadruplici appendice instruxit Alex. Aug. de Buchholtz, doctor iuris utriusque, Borussia 1828, s. 315, przyp. 134; B. Albanese, Le situazioni possessorie nel diritto privato romano, s. 99.

35 Palingenesia iuris civilis iuris consultorum reliquiae quae iustiniani Digestis continentur ceteraque iuris prudentiae civilis fragmenta mimora secundum ductores et libros, ed. O. Lenel, vol. I-II, Lipsiae 1889. s. 1276 (Paulus, nr 1782); M. Kaser, Fragmentum Vaticanum 1, „Labeo” 1961, vol. 7, s. 291; P. Voci, Modi di acquisto della proprierà, s. 197; L. Chiazzese, Confronti testuali. Contributo alla dottrina della interpolazioni giustinianee, AUPA, 1931, t. 16, s. 195; F. Wieacker, Textstufen klassischer Juristen..., s. 326-327; E. Levy, Westen und Osten in der nachklassichen Entwicklung des römischen Rechts, ZRG RA, 1929, t. 49, s. 234, przyp. 3 .

Artykuły - Articles 
cówki fragmentu D. 18,1,2736. W literaturze wskazuje się, że porównanie cytowanego fragmentu i tekstu zawartego w D. 18,1,27 najlepiej obrazuje fakt, iż we Fragmentach Watykańskich przechowano usunięte później instytucje prawa klasycznego ${ }^{37}$. Tym więcej miejsca warto poświęcić analizie Fragmentu Watykańskiego 1.

FV. 1: [Qui a muliere] sine tutoris auctoritate sciens rem mancipi emit, vel falso tutore auctore quem sciit non esse, non videtur bone fide emisse; itaque ut ueteres putant et Sabinus et Cassius scribunt. Labeo quidem putabat nec pro emptore eum possidere, sed pro possessore, Proculus et Celsus pro emptore; quod est verius: nam et fructus suos facit, quia scilicet voluntate dominae percipit et mulier sine tutoris auctoritate possessionem alienare potest. Iulianus propter Rutilianam constitutionem eum, qui praetium mulieri dedisset, etiam usucapere, et si ante usucapionem offerat mulier pecuniam, desinere eum usucapere ${ }^{38}$.

Kto od kobiety bez zgody opiekuna świadomie res mancipi kupił albo z upoważnienia fałszywego opiekuna, o którym wiedział, że nim nie jest, nie uważamy, że kupił w dobrej wierze; tak jak sądzili veteres i pisali Sabinus oraz Kasjusz. Labeo jednakże sądził, że nie posiada ten pro emptore, ale pro possessore. Proculus i Celsus sądzili, że pro emptore, co jest bliższe prawdy. Tak jak owoce swoimi czyni ten mianowicie, który zbiera je z woli właścicielki, tak i kobieta bez zgody opiekuna może przenieść posiadanie. Julian z uwagi na konstytucję Rutiliana twierdzi, że jeśli dał kobiecie zapłatę, to będzie miało miejsce zasiedzenie, i jeśli przed zasiedzeniem kobieta zaofiaruje pieniądze, przerywa to zasiedzenie.

Cytowany fragment warto w celu jego analizy podzielić na trzy części. Pierwsza zaczyna się od słów Qui a muliere, a kończy na sformułowaniu: et Sabinus et Cassius scribunt. Druga to ta od fragmentu Labeo quidem putabat do quod est verius. Trzecia stanowi końcową część FV. 1 (od nam et fructus). Każda z nich to w zasadzie pewna część, dotykająca innego aspektu problemu omawianego przez jurystów. Co ciekawe, każda z tych części w różnym stopniu podejrzana jest o interpolację.

\section{Część pierwsza - Qui a muliere ... scribunt}

Autentyczność i znaczenie pierwszego fragmentu cytowanego tekstu nie budzą istotnych wątpliwości wśród romanistów ${ }^{39}$. Niemniej spotykamy się z pewnymi zastrzeżeniami, które omówimy, aczkolwiek wyłącznie dla porządku. Nie mają one bowiem istotnego znaczenia dla zrozumienia treści pierwszej części wypowiedzi Paulusa.

Zacznijmy od zmiany, która jest faktem i została wprowadzona już przez dziewiętnastowiecznych redaktorów. Pierwsze trzy słowa tekstu (Qui a muliere) są przez nich

36 H. Hausmaninger, Die bona fides des ersitzungsbesitzers im klassischen römischen recht, Wien-München 1964, s. 14 i tam podana literatura.

37 O.F. Robinson, The Sources of Roman Law: Problems and Methods for Ancient Historians, LondonNew York 2006, s. 84, 95, przyp. 30.

38 Iuris civilis anteiustinianei vaticana fragmento e codice rescripto ab Angelo Maio edita recognovit, commentario tum critic tum exegetico nec non quadruplici appendice instruxit Alex. Aug. de Buchholtz, doctor iuris utriusque, Borussia 1828..., s. 1-2.

39 M. Kaser, Fragmentum Vaticanum 1, s. 292. 
dodane, począwszy od wydania Fragmentów Watykańskich przez Angelo $\mathrm{Mai}^{40}$, a następnie powtarzane przez Th. Mommsena ${ }^{41}$, P. Krügera ${ }^{42}$, O. Lenela ${ }^{43}$ i E. Levy'ego ${ }^{44}$ - zachowany tekst Fragmentów Watykańskich zaczyna się od słów sine tutoris auctoritate ${ }^{45}$. W literaturze zwraca się także uwagę na występującą w tekście elipsę. We fragmencie quem sciit non esse pominięto słowo tutorem - po usunięciu wyrzutni powinien on brzmieć: quem sciit tutorem non esse ${ }^{46}$. Max Kaser wskazuje, że może to być wynik pracy kopistów ${ }^{47}$.

Poza powyższym oryginalność dwóch fragmentów pierwszej części FV. 1 poddawana jest $\mathrm{w}$ literaturze krytyce $\mathrm{w}$ bardzo ograniczonym stopniu - jedynie przez S. Solazziego ${ }^{48} \mathrm{w}$ zakresie sformułowania falsus tutor ${ }^{49}$. Trzeba jednak przyznać, że zastrzeżenia S. Solazziego do oryginalności przedmiotowego fragmentu zostały uzasadnione stosunkowo lakonicznie. Jego uwagi, jak zauważył M. Kaser, mają sens tylko wtedy, gdy uznamy język prawników klasycznych za równie sztywny i techniczny jak współczesnych dogmatyków prawa. Tymczasem język prawniczy w okresie klasycznym ulegał ciągłej ewolucji, która de facto nigdy się nie zakończyła ${ }^{50}$. W rezultacie brak jest przekonujących przesłanek, aby uznać, że zamieszczony w FV. 1 zwrot falsus tutor nie jest oryginalny ${ }^{51}$. Uwagę S. Solazziego należy więc potraktować jako jedno z wielu raczej nieuzasadnionych podejrzeń o interpolacje pochodzących z epoki „polowania na interpolacje" ${ }^{52}$.

Po analizie ewentualnych interpolacji przejdźmy do wyjaśniania znaczenia pierwszej części FV. 1. Kobieta sui iuris ${ }^{53}$ bez zgody opiekuna albo z upoważnienia fałszywego opiekuna sprzedała res mancipi nabywcy. Ten zaś doskonale o tych okolicznościach wiedział. Jurysta będący autorem cytowanej wypowiedzi nie miał wątpliwości, że w tej sytuacji nabywający nie robił tego w dobrej wierze, na co zresztą znalazł poparcie w wypowiedziach zarówno nieokreślonych veteres, jak i Sabinusa oraz Kasjusza. Konkluzja ta wydaje się oczywista ${ }^{54}$. W literaturze uznaje się, że tekst ten odnosi się do możliwości

40 Iuris romani anteiustininianei fragmenta vaticana e codice palimpsesto, red. A. Maius, RomaeBerolini 1824, s. 1; Locorum ex iure Romano anteiustiniano ab incerto scriptore collectorum fragmenta quae dicuntur vaticana, red. A. Maius, rec. A. Bethman-Hollweg, Bonnae 1833, s. 1.

41 Codicis vaticani $n .5766$ in quo insunt iuris anteiustiniani fragmenta quae dicuntur vaticana. Exemplum addita transcriptione notisque criticis, ed. Th. Mommsen, Berolini 1860, s. 267.

42 Digesta. Corpus Iuris Civilis, vol. I, Th. Mommsen, P. Krüger, Berolini 1954, s. 264, przyp. 12.

43 Palingenesia..., vol. I, s. 158.

44 E. Levy, Westen und Osten in der nachklassischen Entwicklung..., s. 234.

45 Codicis vaticani n. 5766..., s. 266; Por. G. Wesenberg, Fr. 18 Pr. D. 41, 2. Ein Beitrag zur Lehre vom Constitutum Possessorium [w:] Studi in memoria di Emilio Albertario, t. II, Milano 1953, s. 58; M. Kaser, Fragmentum Vaticanum 1, s. 292.

46 S. Solazzi, Quod falso tutore auctore gestum esse dicatur [w:] idem, Scritti di diritto romano, t. II, Napoli 1957, s. 600.

47 M. Kaser, Fragmentum Vaticanum 1, s. 295.

48 S. Solazzi, Quod falso tutore..., s. 600.

49 M. Kaser, Fragmentum Vaticanum 1, s. 296.

50 Ibidem, s. 294-295.

51 H. Hausmaninger, Die bona fides..., s. 14.

52 Por. K. Sorka, Interpolacje „Digestów” justyniańskich. Rys historyczno-metodologiczny, „Forum Prawnicze" 2017, nr 5, s. 58-62 i tam podana literatura.

53 P. Voci, Modi di acquisto..., s. 196.

54 Por. A. Watson, The Law of Property..., s. 54. 
zasiedzenia rzeczy, choć nie wynika to z niego wprost ${ }^{55}$. Max Kaser zwrócił uwagę, że sam fakt pojawienia się takiego tekstu wskazuje, iż stanowisko to musiało budzić pewne kontrowersje i niektórzy juryści musieli w takiej sytuacji uznawać istnienie dobrej wia$\mathrm{ry}^{56}$. Nie wydaje się to jednak zasadne rozumowanie. Owszem, taka ocena jest możliwa, niemniej nie konieczna. Równie dobrze można sobie wyobrazić sytuację, w której wśród prawników rzymskich (początkowo veteres) pojawia się konieczność oceny przedstawionych okoliczności faktycznych i wszyscy oni zgodnie wskazują rozwiązanie. Tym samym powołanie się w cytowanym źródle na veteres, Sabinusa i Kasjusza, może oznaczać tylko tyle, że problem ten stał się przedmiotem rozważań veteres, Sabinusa i Kasjusza, którzy rozstrzygnęli go w ten sam sposób. Nie musi to oznaczać istnienia przeciwstawnego stanowiska wśród innych jurystów.

Podsumowując, z pierwszej części FV. 1 wynika, że veteres, Sabinus, Kasjusz i wreszcie Paulus, dostrzegli brak dobrej wiary wtedy, gdy nabywający res mancipi w dobrej wierze wiedział, że sprzedająca ją kobieta sui iuris nie miała wymaganej zgody opiekuna albo osoba, która takiej zgody udzieliła, była fałszywym opiekunem. Z kontekstu wypowiedzi i dalszej części źródła wynika, że brak bona fides w takim przypadku skutkował brakiem możliwości zasiedzenia res mancipi.

\section{Część druga - Labeo quidem ... quod est verius}

O ile do fragmentu Sabinus et Cassius scribunt tekst nie rodzi większych wątpliwości, o tyle problemy interpretacyjne pojawiają się już przy lekturze drugiej części FV. 1. Przedstawiono w niej stanowiska trzech jurystów.

Labeon twierdzil, że w przedstawionej sytuacji mamy do czynienia raczej z posiadaniem pro possessore niż pro emptore, czemu sprzeciwili się Prokulus i Celsus. Paulus przychylił się do stanowiska Prokulusa i Celsusa. W literaturze wskazuje się, że zdaniem Labeona w zaistniałej sytuacji mamy do czynienia z nieważną umową kupna-sprzedaży i z uwagi na to z posiadaniem pro possessore, nie zaś pro emptore $e^{57}$ - co M. Kaser odnosi wprost do tytułu zasiedzenia ${ }^{58}$. Pogląd Labeona jest tym samym dalej idący niż veteres, Sabinusa i Kasjusza, gdyż nie tylko kwestionuje on istnienie dobrej wiary, ale także iusta causa usucapionis w postaci tytułu pro emptore ${ }^{59}$. Natomiast Prokulus i Celsus przyjęli, że w zaistniałej sytuacji sama umowa kupna-sprzedaży jest skuteczna, gdyż o jej ważności nie decyduje zgoda opiekuna ${ }^{60}$.

Z tekstu nie wynika, czy wobec tego zdaniem Prokulusa i Celsusa w omawianym stanie faktycznym zaistniała dobra wiara, a co za tym idzie - czy zasiedzenie było możliwe.

55 Ibidem, s. 54-55.

56 Ibidem, s. 293.

57 E. Pool, Significati diversi di causa in tema di possessio e di usucapio, Interpretazioni di qualche testo chiave, parte 1, AUPA, 2016, t. 59, s. 61; H. Hausmaninger, Die bona fides..., s. 18-19.

58 M. Kaser, Fragmentum Vaticanum 1, s. 300.

59 A. Pernice, Labeo. Römisches Privatrecht in Ersten Jahrhundert der Kaiserzeit, Teil C, Band 2 Abteilund 1 in 2. Auflage 7. Buch: Dolus malus und bona fides, 1895, reprint. Allen 1963, s. 466.

${ }^{60}$ K. Bauer, Die rutiliana constitutio des Julian, TR, 1986, t. 1, passim. 
Zdaniem P. Vociego w odróżnieniu od veteres, Sabinusa i Kasjusza, Prokulus i Celsus dostrzegli w omawianym przypadku dobrą wiarę. Nie znajduje to jednak oparcia w źród$1 \mathrm{l}^{61}$. To, że Prokulus i Celsus dostrzegli tytuł pro emptore, nie implikuje uznania dobrej wiary. Nie pozwala także na przyjęcie, że w przedmiotowym stanie faktycznym zdaniem Prokulusa i Celsusa doszło do zasiedzenia rzeczy. Z cytowanego tekstu wynika, że stanowisko Prokulusa i Celsusa było ustawione w kontrze do poglądu Labeona, a nie do opinii veteres, Sabinusa i Kasjusza. Poparte przez nich rozwiązanie wydaje się wręcz korespondować ze stanowiskiem Prokulusa i Celsusa. Zwróćmy uwagę, że poszczególne poglądy jurystów są w tekście wykorzystywane przez Paulusa raczej dość instrumentalnie - nie są przywoływane całościowo i wyjęte zostały z pierwotnego kontekstu. Nie wiemy więc, czy Prokulus i Celsus zastanawiali się nad istnieniem dobrej wiary w sytuacji analizowanej przez veteres, Sabinusa i Kasjusza. Wiemy, że Prokulus i Celsus dostrzegli $\mathrm{w}$ takich okolicznościach faktycznych tytuł pro emptore i zapewne zrobili to w kontrze do wypowiedzi Labeona. Układ tekstu Paulusa jest więc następujący: najpierw przywołuje on stanowisko dotyczące dobrej wiary, które popiera. Następnie wskazuje, że przyjęte przez niego rozwiązanie - zaakceptowane także przez veteres, Sabinusa i Kasjusza - podważa stanowisko Labeona dotyczące braku iusta causa w postaci emptio-venditio. Wówczas Paulus wskazuje, że stanowisko to zostało zakwestionowane przez Prokulusa i Celsusa, a on sam z krytyką tą się zgadza. W rezultacie przekazany w pierwszej części FV. 1 pogląd Paulusa pozostaje aktualny.

Podsumujmy analizę dwóch pierwszych części FV. 1. W pierwszej autor tekstu daje nam odpowiedź na pytanie o to, czy mamy do czynienia w przedstawionych okolicznościach faktycznych z dobrą wiarą po stronie nabywcy rzeczy. Przytacza stanowisko veteres, Sabinusa i Kasjusza, którzy zgodnie uznali, że nie możemy tutaj mówić o dobrej wierze.

Zwróćmy jeszcze uwagę na jedną prawidłowość. Otóż w pierwszym z analizowanych fragmentów autor przytacza poglądy Sabinusa i Kasjusza, a więc prawników należących do szkoły Sabinianów. W drugim zaś mowa jest o stanowisku Labeona, Prokulusa i Celsusa, a więc Prokulianów. Trudno orzec jednoznacznie, czy zabieg ten był celowy, na co nie pozwalają też trudności z określeniem natury podziału pomiędzy tymi szkołami $^{62}$.

\section{Tutela mulieris}

Zanim przejdziemy do ostatniej części FV. 1, pójdźmy za radą H. Hausmaningera i zastanówmy się, co wiemy o zakresie opieki nad kobietą sui iuris i skutkach jej braku w kontekście umowy kupna-sprzedaży i zasiedzenia res mancipi ${ }^{63}$. Co istotne, nie wiemy dużo. Znana ustawie XII Tablic instytucja tutelae mulieris już w I w. przed Chr.

61 P. Voci, Modi di acquisto..., s. 197.

62 P. Stein, The Two Schools of Jurists in the Early Roman Principate, „Cambridge Law Journal” 1972 , t. 31, s. 8 .

63 H. Hausmaninger, Die bona fides..., s. 20. 
straciła na znaczeniu ${ }^{64}$. Szczególne tyczy się to najbardziej uciążliwej dla kobiety opieki tutela agnati ${ }^{65}$, zniesionej przez lex Claudia ${ }^{66}$. Z czasem omawiana tutaj instytucja została całkowicie wyeliminowana $\mathrm{z}$ obrotu prawnego, podobnie jak podział rzeczy na mancipi i nec mancipi. Po lex Claudia tutela utrzymała się najprawdopodobniej jedynie w stosunku do wyzwolenic i powoli zanikała na początku III w. po Chr. ${ }^{67} \mathrm{~W}$ kompilacji Justyniańskiej brak bezpośrednich odniesień do tutelae mulieris, szczególnie w kontekście res mancipi. W niektórych źródłach tutela mulieris została zmieniona przez kompilatorów na opiekę nad małoletnimi kobietami (tutela pupillare) ${ }^{68}-$ D. 18,1,27; D 23,3,5,12.

Jak wskazuje się w literaturze, funkcja opiekuna sprowadzała się do wyrażenia zgody na czynności kobiety (auctoritas tutoris), a i ta funkcja była znacznie ograniczona ${ }^{69}$. Kobieta mogła sama zarządzać swoim majątkiem, a zgoda opiekuna konieczna była tylko w niektórych przypadkach ${ }^{70}$, między innymi na zbycie res mancipi przez kobietę, na co wskazują dwa źródła ${ }^{71}$ : G. 2,80 i Tituli ex Corpore Ulpiani 11,27. Nie są to oczywiście jedyne takie źródła ${ }^{72}$, niemniej na potrzeby niniejszego opracowania omówienie tych dwóch wydaje się wystarczające.

Zacznijmy od przywołania G. 2,80.

G. 2,80: Nunc admonendi sumus neque feminam neque pupillum sine tutoris auctoritate rem mancipi alienare posse; nec mancipi vero feminam quidem posse, pupillum non posse.

Następnie zauważmy, że ani pupil, ani kobieta bez zgody opiekuna nie mogą zbyć res mancipi; i nawet res nec mancipi, które kobieta może (zbyć), a pupil nie może.

Tekst ten, w przywołanej powyżej formie, zasadniczo odpowiada treści Gaiańskiego palimpsestu. $\mathrm{Z}$ tym zastrzeżeniem, że zamiast sformułowania sine tutoris auctoritate używa się tam skrótu $s t a^{73}$. Z tekstu Gaiusa wynika wprost, że na zbycie res mancipi przez kobietę potrzebna była zgoda opiekuna, co nie tyczyło się już res nec mancipi.

Tituli ex Corpore Ulpiani 11,27: Tutoris auctoritas necessaria est mulieribus quidem in his rebus: si lege aut legitimo iudicio agant, si se obligent, si civile negotium gerant, si libertae suae permittant in contubernio alieni servi morari, si rem mancipi alienent. Pupillis autem hoc amplius etiam in rerum nec mancipi alienatione tutoris auctoritate opus est.

64 P. Bonfante, Forme primitive ed evoluzione della proprietà romana (,, Res mancipi” e „res nec mancipi”) [w:] Scritti giuridici varii, t. 2: Proprietà e servitù, Milano-Napoli-Palermo-Roma 1918, s. 189.

65 Ibidem.

66 M. Zabłocka, Zanikanie instytucji tutela mulierum $w$ prawie rzymskim, „Prawo Kanoniczne” 1987 , t. 30 , nr 3-4, s. 247.

${ }^{67}$ Ibidem, s. 252; W. Kozubski, Opieka nad kobietami w prawie rzymskim, Kraków 1922, s. 34; B. Biondi, Istituzioni di diritto romano, wyd. 3, Milano 1956, s. 595.

68 D. $18,1,27$; D. 23,3,5,12.

69 D. Johnston, Roman Law in Context, Cambridge 2007, s. 39.

70 A. Watson, The Law of Persons in the Later Roman Republic, Oxford 1984, s. 149.

71 G. 2,81, Tituli ex Corpore Ulpiani 11,27.

72 Por. FV. 259 i FV. 264.

73 Por. M. David, H.L.W. Nelson, Gai institutionum commentarii IV mit philohogischem kommentar herausgegeben, Studia Gaiana III, Leiden 1960, s. 291-292. 
Zgoda opiekuna konieczna jest dla kobiety nawet w takich przypadkach: jeśli wnosi skargę, jeśli się zobowiązuje, jeśli zawiera czynność prawną prawa cywilnego, jeśli swojej wyzwolenicy pozwala przebywać $\mathrm{w}$ związku z obcym niewolnikiem, jeśli zbywa res mancipi. Pupil zaś ponadto także w przypadku zbywania res nec mancipi potrzebuje zgody opiekuna.

Fragment ten zawiera wyliczenie czynności, które wymagały zgody opiekuna, a wśród nich zbycie res mancipi. Warto zwrócić uwagę, że zarówno w G. 2,80, jak i Tituli ex Corpore Ulpiani 11,27 mowa jest o zbyciu (alienare) rzeczy. Zakaz musiał więc obejmować każdą formę przeniesienia własności o charakterze pochodnym. Oba źródła tylko częściowo korespondują więc z omawianym przez nas FV. 1. Nie odnoszą się wprost do emptio-venditio, a ich autorzy posługują się pojęciem alienare. Trudno zatem jednoznacznie stwierdzić, czy zgoda wymagana była już, aby zawrzeć ważny kontrakt, czy też jej brak skutkował jedynie tym, że nie dochodziło do przejścia własności. Nie można wykluczyć sytuacji, w której w wyniku emptio-venditio nie mogło dojść do rozporządzenia rzeczą wobec braku zgody opiekuna, ale nie wykluczało to jej zasiedzenia.

Zauważmy jednak, że o kwestii zasiedzenia res mancipi bez zgody opiekuna wprost wypowiedział się Gaius w swoich Instytucjach, powołując się na ustawę XII Tablic. Niemniej nie jest to źródło, na podstawie którego możemy wyciągnąć jednoznaczne wnioski. Sama jego treść budzi bowiem wątpliwości ${ }^{74}-\mathrm{w}$ kontekście prawidłowego odczytania palimpsestu. Nadto na tyle mało wiemy o funkcjonowaniu instytucji zasiedzenia w czasach ustawy XII Tablic, że trudno opierać się na pojedynczej wypowiedzi Gaiusa. Szczególnie że raczej nie budzi wątpliwości wśród romanistów to, że klasyczne usucapio różniło się od rozwiązania znanego prawu archaicznemu ${ }^{75}$.

W palimpseście Instytucji Gaiusa fragment G. 2,47 ma następującą treśćc ${ }^{76}$ :

G. 2,47 Res mulieris que in agnatum tutela erant res mancipi usucapi non poterant, praeterquam si ab ipsa tutore tradita essent id ita legem XII tabularum cautum errat.

Fragment ten budzi w literaturze uzasadnione wątpliwości. Powszechnie przyjmuje się, że wymaga on pewnych uzupełnień. Należy bowiem pamiętać, że istnienie glos poklasycznych do Instytucji Gaiusa nie jest sporne ${ }^{77}$, choć można się spierać o zakres ingerencji pogaiańskich kopistów ${ }^{78}$. W szczególności wskazuje się, że w tekście pojawiają się dwa podmioty - res mulieris i res mancipi, co świadczy o występujących w nim lukach $^{79}$. Aby tę lukę wypełnić, w piśmiennictwie proponowano dodanie na początku fragmentu zwrotu item albo item olim i usunięcie słowa res ${ }^{80}$. Zwrot item olim dodawano z uwagi na to, że według dostępnych nam przekazów w czasach Gaiusa przywołana przez niego reguła nie mogła obowiązywać. Za pomocą Lex Claudia de tutela mulierum,

74 P. Bonfante, Forme primitive ed evoluzione della proprietà romana..., s. 30.

75 Por. G. Diósdi, Ownership in Ancient and Preclassical Roman Law, Budapest 1970, s. 85, przyp. 1.

$76 \mathrm{Wg}$ wydania Gai instutitutiones codicis veronensis apographum ad Goescheni Hollwegi Bluhmii schedas conpositum scripsit lapidibusque exceptam scripturam publicavit Eduardus Böcking, Lipsiae 1866, s. 65 .

77 A. Guarino, L'esegesi delle fonti del diritto romano, Napoli 1968, s. 445 i tam podana literatura.

78 E. Albertario, Studi di diritto romano, t. V, Milano 1937, s. 441-442 i tam podana literatura.

79 M. David, H.L.W. Nelson, Gai institutionum commentarii IV ..., s. 262.

80 Ibidem. 
przyjętej za cesarza Klaudiusza ${ }^{81}$, zniesiono bowiem opiekę agnacyjną nad kobietą̨ ${ }^{82}$ Co ciekawe, ustawa ta jest wprost przywoływana w niektórych rekonstrukcjach przedmiotowego tekstu, poprzez dodanie na przykład sformułowania item ante legem Claudiam, si erant ${ }^{83}$. Tymczasem termin olim ,wskazuje na prawo już nie obowiązujące i jako takie nie przedstawiające dla prawnika klasycznego w zasadzie żadnej wartości”" ${ }^{\prime}$.

W piśmiennictwie nie budzi natomiast wątpliwości, że słowo auctore po sformułowaniu tutore kopiści przypadkowo pominęli ${ }^{85}$.

W konsekwencji dość powszechnie fragment G. 2,47 przywołuje się w następującej treści ${ }^{86}$ :

G. 2,47 < Item olim> mulieris, quae in agnatorum tutela erat, res mancipi usucapi non poterant, praeterquam si ab ipsa tutore <auctore> traditae essent: idque ita lege XII tabularum cautum errat.

Niemniej taki sposób rekonstrukcji tekstu G. 2,47 został poddany krytyce w komentarzu do tego fragmentu opracowanym przez M. Davida i H.L.W. Nelsona ${ }^{87}$, którzy skłonili się do uznania, że sformułowanie res mancipi stanowi glosę do oryginalnego tekstu Gaiusa $^{88}$. Zaproponowali oni następującą rekonstrukcję tekstu ${ }^{89}$ :

G. 2,47 Res mulieris <quoque>, quae in agnatorum tutela errat, [res mancipi] usucapi non poterant, praeterquam si ab ipsa tutore < auctore $>$ traditae essent: et ita lege XII tabularum cautum est.

Stosownie do tej rekonstrukcji zakazowi zasiedzenia podlegałyby nie tylko res mancipi, ale wszystkie rzeczy. Stanowisko takie spotkało się w literaturze z krytyką, z uwagi na brak jakichkolwiek innych przekazów źródłowych, z których wynikałoby rozciągnięcie zakazu zasiedzenia rzeczy także na res nec mancipi ${ }^{90}$. Wydaje się jednak, że sama rekonstrukcja M. Davida i H.L.W. Nelsona nie musi pociągać za sobą uznania, że Gaius rozciągał zakaz zasiedzenia na inne rzeczy niż res mancipi. Jeśli bowiem założymy, że autorzy poklasyczni dopisali do tekstu Instytucji zwrot res mancipi, to mogli to zrobić w jednym tylko celu - poprawienia autora. Być może w oryginalnym tekście Instytucji zabrakło wzmianki o res mancipi, którą uzupełnili późniejsi autorzy. Pamiętajmy jednak, że komentując dziś treść zachowanych do naszych czasów źródeł, zapominamy często o jednej rzeczy - w oryginale także mogły pojawić się błędy. Równie prawdopodobne

81 R. Taubenschlag s.v. Lex Claudia, RE, 12.2, s. 2340-2341.

82 G. 1,157. A. Berger, Encyclopedic Dictionary of Roman Law, Philadelphia 1980, s. 549.

83 Gai institutiones iuris civilis rom. Secundum Guilelmi Studemund cod. Ver. Collationem edid. Emend. Notisque illustravit. Appositis Iustiniani Institutionibus, iis quidem ex recensione Pauli Krueger fere repetitis, ad locos deperditos lumina adiecit ex Epitome Gaiana, Ulpiani Fragmentis allisque B.J. Polenaar, Lugduni Batavorum, 1876, s. 41.

${ }_{84}$ T. Giaro, Prawda dogmatycza..., z. 1, s. 13.

85 M. Kaser, Altrömisches Eigentum und ,, usucapio”, ZRG RA, 1988, t. 105, s. 153-154, przyp. 161.

${ }_{86}$ Gai institutiones ad codicis veronensis apographum studemundianum in usum scholarum, red.

P. Krueger, G. Studemund, Berolini 1877, s. 47.

87 M. David, H.L.W. Nelson, Gai institutionum commentarii $I V$..., s. 262.

88 Ibidem, s. 263-264.

89 Gai institutionum commentarii IV mit philologischem kommentar herausbeben von M. David und H.L.W. Nelson, Leiden 1960, s. 75. Por. H. Hausmaninger, Die bona fides ..., s. 20.

90 A. Katančević, Bona fides као услов узукапије у класичном римском праву, Belgrad 2012, s. 63. 
jak to, że tekst Gaiusa został poddany zmianom w późniejszym czasie, jest to, że sam Gaius popełnił błąd.

Według G. 2,47 res mancipi należące do kobiety nie mogły być zatem zasiedziane, jeśli nie zostały wydane (za pomocą traditio) za zgodą agnacyjnego opiekuna ${ }^{91}$. Max Kaser wskazuje, że G. 2,47 to jedyne znane dziś źródło odnoszące się do tej zasady ${ }^{92}$, które dodatkowo miało już dla autora Instytucji jedynie znaczenie historyczne ${ }^{93}$. Zdaniem H.F. Jolowicza reguła ta została następnie zmieniona przez constitutio Rutiliana, do czego odniesiemy się, analizując trzecią część FV. $1^{94}$. W literaturze znane jest także stanowisko, zgodnie z którym z fragmentu tego wynika, że res mancipi przeniesione bez zgody opiekuna były wyjęte spod kategorii res habiles - rzeczy nadających się do zasiedzenia ${ }^{95}$. Zauważmy również, że w G. 2,47 mowa jest o tutela agnatum, podczas gdy omawiane wcześniej źródła odnoszą się do tuteli jako takiej.

Poza tekstami prawniczymi kwestia zgody opiekuna w kontekście zasiedzenia res mancipi poruszona została jeszcze w jednym z listów Cycerona do Attyka.

Cic. Ad Att. 1,5,6 de Tadiana re mecum Tadius locutus est te ita scripsisse, nihil esse iam quod laboraretur, quoniam hereditas usu capta esset. id mirabamur te ignorare, de tutela legitima, in qua dicitur esse puella, nihil usu capi posse.

Co się tyczy sprawy Tadiusza. Powiedział mi on, że napisałeś mu, iż nie ma już po co się trudzić, ponieważ spadek został zasiedziany, dziwi mnie, że nie wiesz, iż z powodu opieki prawnej, w którą oddana została dziewczyna, nie można zasiedzieć.

Nie znamy kontekstu listu. Dlatego trudno nam dziś odtworzyć stan faktyczny, o którym pisał Cyceron. Wiemy tyle, że dotyczył on sytuacji Tadiusza - najprawdopodobniej jednego z dwóch braci: Publiusza Tadiusza albo Quintusa Tadiusza (obydwaj wspomniani w mowie Cycerona przeciwko Werresowi $)^{96}$. $Z$ wypowiedzi Arpinaty wynika jednak, że w jego czasach obowiązywał zakaz dotyczący zasiedzenia, powiązany z oddaniem kobiety pod tutela legitima. Znając przekaz Gaiusa (G. 2,45), możemy się tylko domyślić, że mowa o zakazie zasiedzenia res mancipi z uwagi na brak zgody opiekuna. $\mathrm{O}$ ile jednak Gaius wypowiadał się odnośnie do materii historycznej, o tyle Cyceron wyraźnie mówi o prawie obowiązującym w jego czasach. Można by wręcz pokusić się o stwierdzenie, że była to norma prawna często stosowana i powszechnie znana w określonych kręgach elity rzymskiej - na co może wskazywać swego rodzaju wytknięcie przez Cycerona Attykowi braku, wydawałoby się tak pospolitej, wiedzy. Niemniej równie dobrze Cyceron mógł wykorzystać sprawę Tadiusza do wykazania się swoją erudycją prawniczą, podkreślając, jak oczywista jest dla niego wiedza, która nie musiała być $\mathrm{w}$ jego czasach powszechna.

91 A. Watson, The Law of Persons in the Later Roman Republic, s. 22. A. Watson, Rome of the XII Tables. Persons and Property, New Jersey 1975, s. 155; B. Albanese, Le situazioni possessorie ..., s. 95, przyp. 337.

92 M. Kaser, Eigentum und Besitz. Im älteren Roömischen Recht, Köln-Graz 1956, s. 98-99.

93 Ibidem, s. 101.

94 H.F. Jolowicz, Historical Introduction to the Study of Roman Law, Cambridge 1932, s. 155.

95 P. Bonfante, Corso di diritto romano, t. I, Roma 1925, s. 410; M.T. Nicotri, De dote quantitate. A proposito di Cels. D. 23.3.60 e 32.43, „Teoria e Storia del Diritto Privato” 2011, t. 4, s. 17, przyp. 24, http://www. teoriaestoriadeldirittoprivato.com/index.php?com=statics\&option=index\&cID=207 (dostęp: 01.05.2018).

96 Ciceor's Letters to Atticus, red. D.R. Shackleton Bailey, t. I, Cambridge 1965, s. 279. 
Wydaje się, że powyżej przywołano i omówiono wszystkie ważne dla naszych rozważań znane nam teksty dotyczące auctoritas tutoris w kontekście zasiedzenia res mancipi. Ciekawe, że w literaturze przywoływane są w tym kontekście także inne źródła, choć $\mathrm{w}$ rzeczywistości nie mają one z tym tematem wiele wspólnego. Fragment z mowy Cycerona w obronie Flakkusa (Cic. Pro Flacco 34,84) odnosi się bowiem do kwestii zgody opiekunów na wejście pod władzę męża poprzez usus lub coemptio ${ }^{97}$ - a nie, jak się czasem wskazuje w literaturze, usucapio ${ }^{98}$. Jeśli ma znaczenie dla badań instytucji zasiedzenia, to tylko ograniczone ${ }^{99}$.

\section{Część trzecia - nam et fructus ... usucapere}

Ostatni fragment FV. 1 rodzi najwięcej problemów interpretacyjnych. Budzi on też największe zastrzeżenia pod kątem autentyczności. Zacznijmy więc od oceny oryginalności tekstu.

Niektórzy romaniści wskazują, że prawnicy klasyczni nie używali sformułowania alienare possessionem ${ }^{100}$ bądź też nie było ono dla nich typowe ${ }^{101}$. Interesujące, że w literaturze nie poświęcono temu sformułowaniu wiele miejsca. Fryderyk Karol Savigny tłumaczył alienare possessionem jako jednocześnie utratę posiadania i danie początku następstwu prawnemu (Allein alienare possessionem heisst so den Besitz verlieren, dass darin eine juristische Succession liegt ${ }^{102}$. W literaturze na gruncie D. 41,1,11 wskazuje się na rozróżnienie pomiędzy utratą przez pupila posiadania corpore a możliwością zgodnego z prawem przeniesienia posiadania (alienare) ${ }^{103}$. Rzeczywiście, sformułowanie to nie występuje w źródłach poza omawianym tutaj fragmentem. Dlatego trudno stwierdzić, czy jest ono, czy też nie jest typowe dla jurystów klasycznych - to, że zachowało się ono we Fragmentach Watykańskich, a nie w Digestach, pozwala łatwiej przyjąć tezę o klasyczności tego sformułowania.

Drugi zauważany w literaturze problem autentyczności tekstu dotyczy sformułowania propter Rutilianam constitutionem. Karen Bauer zajęła nawet stanowisko, zgodnie z którym powołanie się na rzekomą konstytucję Rutyliana stanowi pomyłkę kopistów a w rzeczywistości taki dokument nie istniał ${ }^{104}$. Stanowisko to znajduje uznanie wśród innych romanistów ${ }^{105}$, aczkolwiek wielu z nich (co jednak trzeba przyznać, przed opub-

97 A. Watson, The Law of Persons in the Later Roman Republic, s. 147.

98 Por. H.J. Roby, Roman Private Law in the Times of Cicero and of the Antonines, t. I, New Jersey 2000 (reprint, oryg.: Cambridge 1902), s. 68; A. Watson, The Law of Persons in the Later Roman Republic, s. 21.

99 Th. Mayer-Maly, Studien zu Frühgeschichte der usucapio II, ZRG RA, 1961, t. 78, s. 262-264.

100 M. de Filippi, Fragmenta Vaticana. Storia di un testo normativo, Bari 1998, s. 104.

101 A. Manzo, Magnum munus de iure respondendi substinebat. Studi su Publio Rutilio Fufo, Milano 2016, s. 103 .

102 F.K. Savigny, Das Rechts des Besitzes: eine civilistische Abhandlung, Wien 1865, s. 356, przyp. 4.

103 H.J. Roby, An Introduction to the Study of Justinians's Digest Containing an Account of Its Composition and of the Jurists Used of Referred to Therein Together with a Full Comentary on the Title (De Usufructu), Cambridge 1884, s. cxxxix.

104 K. Bauer, Die rutiliana constitutio..., s. 99.

105 A. Manzo, Magnum munus..., s. 103. 
likowaniem swojej tezy przez K. Bauer) uznaje autentyczność przekazu o konstytucji Rutyliana ${ }^{106}$.

Autor tekstu zawartego w FV. 1 przychylił się do stanowiska Prokulusa i Celsusa, zgodnie z którym $\mathrm{w}$ omawianych $\mathrm{w}$ tym fragmencie okolicznościach faktycznych mamy do czynienia z posiadaniem pro emptore. W trzeciej części FV. 1 wyjaśnia swoje stanowisko. Po uwagach dotyczących autentyczności tekstu przyjrzyjmy się temu uzasadnieniu.

Jurysta stwierdza, że jeśli ktoś zbiera za zgodą właścicielki gruntu owoce, to te stają się jego własnością. Jeśli tak, to kobieta może bez zgody opiekuna przenieść posiadanie. Wygląda na to, że dla współczesnych autorowi tekstu nie budziło wątpliwości, że można nabyć owoce gruntu za zgodą samej właścicielki - a więc bez konieczności uzyskania akceptacji opiekuna. Dla jurysty był to argument za przyjęciem, że także przeniesienie samego posiadania dopuszczalne jest bez zgody tutora. Karen Bauer puentuje, że kobieta jest uprawniona do przeniesienia posiadania i przyznania prawa do pobierania owoców bez zgody opiekuna ${ }^{107}$. Z tekstu zdaje się wynikać, że to dopuszczalność przeniesienia posiadania (alienare possessionem) pozwala przyjąć, że umowa kupna-sprzedaży jest ważna - bez zgody opiekuna ${ }^{108}$. Zdaniem M. Kasera Paulus nie dopuszczał zasiedzenia owoców pozyskanych w wyniku wykonywania prawa do pobierania owoców z uwagi na brak bona fides ${ }^{109}$. To samo można odnieść do posiadania rzeczy - można je przenieść na kobietę w ten sposób, że będzie ona posiadać pro emptio, jednak brak dobrej wiary uniemożliwi zasiedzenie. Tak wydaje się kształtować stanowisko Paulusa, poparte odwołaniem się do veteres, Sabinusa i Kasjusza, w zakresie bona fidas, i Celsusa oraz Prokulusa, w zakresie possessio pro emptore.

Ostatni fragment interesuje nas w tym miejscu mniej, z uwagi na to, że zasadniczo odnosi się do poglądów Juliana. Ma on dla nas jednak jedno zasadnicze znaczenie - autor tekstu źródłowego wprost wskazuje w nim, że problemem analizowanym w całym FV. 1 jest dopuszczalność zasiedzenia rzeczy ${ }^{110}$. Julian, według autora tekstu, miał bowiem dopuścić w omawianych w FV. 1 okolicznościach zasiedzenie, aczkolwiek tylko w sytuacji zapłaty ceny - co miało stanowić swego rodzaju wyjątek ${ }^{111}$. Zdaniem M. Kasera wynika to $\mathrm{z}$ istoty samego zakazu nabycia własności res mancipi bez zgody opiekuna - w przypadku, gdy kobieta otrzymała ekwiwalent, odpada ryzyko jej pokrzywdzenia ${ }^{112}$. Autor ten zauważył jednak pewną niezgodność pomiędzy takim wnioskowaniem a, wydaje się słusznym, stwierdzeniem o braku dobrej wiary (jako przesłanki zasiedzenia) zawartym w pierwszym fragmencie FV. $1^{113}$. Według Pietro Bonfante fragment mówiący o możli-

106 P. Bonfante, Le singole 'iusta causae usucapionis' e il titulo putativo [w:] idem, Scritti giuridici varii, II, s. 594; idem, Essenza della 'bona fides'e suo rapporto colla teorica dell'errore [w:] idem, Scritti giuridici varii, II, s. 724 .

107 Ibidem, s. 98.

108 E. Pool, Significati diversi di causa in tema di possessio e di usucapio..., s. 81.

109 M. Kaser, Fragmentum Vaticanum 1, s. 293.

110 Por. P. Voci, Modi di acquisto..., Milano 1952, s. 197.

111 Ibidem.

112 Ibidem, s. 294.

113 Ibidem. 
wości przeniesienia posiadania bez zgody opiekuna dotyczy possessio naturalis ${ }^{14}$. Ten sam autor także zwraca uwagę na fakt zapłaty kobiecie wynagrodzenia jako wystarczającą przyczynę (causa) zasiedzenia ${ }^{115}$. Nabycie w jego wyniku własności rzeczy zdaje się w tym kontekście ekwiwalentem otrzymanego przez sprzedawcę wynagrodzenia. Jeśli kobieta zdecyduje się jednak zwrócić cenę, odpadnie przyczyna zasiedzenia (causa pro emptore). Rozwiązanie takie wydaje się z jednej strony skrajnie ograniczać znaczenie zgody opiekuna, w okresie w którym tutela mulieris należy już do rozwiązań archaicznych, z drugiej zaś pozostawia kobiecie furtkę do przywrócenia stanu poprzedniego. Co interesujące, cały fragment FV. 1 zdaje się wskazywać, że problem braku zgody opiekuna na zawarcie umowy kupna-sprzedaży res mancipi istniał jednak jeszcze w czasie Juliana i Paulusa.

\section{D. $18,1,27$}

Jak zauważyliśmy na wstępie, FV. 1 ściśle łączy się w literaturze z D. 18,1,27. Jak dotąd nie omawialiśmy tego źródła, gdyż nie zawiera ono odwołania do poglądów jurystów działających w początkach pryncypatu, których stanowisko nas tutaj interesuje. Niemniej w tym miejscu warto je przywołać. Może ono bowiem przybliżyć szerszy kontekst omawianego przez nas fragmentu i tym samym pozwolić na lepsze jego zrozumienie.

D. 18,1,27 (Paulus libro octavo ad Sabinum) Qui a quolibet rem emit, quam putat ipsius esse, bona fide emit: at qui sine tutoris auctoritate a pupillo emit, vel falso tutore auctore, quem scit tutorem non esse, non videtur bona fide emere, ut et Sabinus scripsit.

Kto od kogokolwiek kupuje rzecz, którą uważa za swoją, kupuje w dobrej wierze; lecz jeśli bez zgody opiekuna od pupila kupił albo za zgodą fałszywego opiekuna, jeśli wiedział, że ta osoba nie jest opiekunem, nie uważamy, że kupił w dobrej wierze, co i Sabinus napisał.

Zwróćmy uwagę, że fragment ten zawarty został w księdze 18 tytule 1 Digestów De contrahenda emptione et de pactis inter emptorem et venditorem compositis et quae res venire non possunt $(\mathrm{O}$ kontrakcie kupna i o umowach między kupującym i sprzedawcą zawartych i rzeczach, które nie mogą być zbywane). Dla kompilatorów istotne było więc zawarte w nim stanowisko Paulusa odnośnie do przesłanki dobrej wiary w kontekście kontraktu emptio-venditio. Rzeczywiście, podobieństwo pomiędzy FV. 1 i D. 18,1,27 jest widoczne na pierwszy rzut oka. Widać, że kobietę zastąpił w tekście pupil, co, jak już wskazaliśmy, wynikało z faktu zaniku instytucji opieki nad kobietą w czasach przedjustyniańskich. Druga istotna zmiana dotyczy braku wzmianki o res mancipi, co także wiąże się z usunięciem tego pojęcia $\mathrm{z}$ języka prawniczego na długo przed opracowaniem Digestów. Co ciekawe, kompilatorzy zdecydowali się powołać wyłącznie na stanowisko Sabiniusa. Wygląda to tak, jakby uznali jego opinię za wystarczającą na potrzeby poparcia stanowiska Paulusa - i wykazania, że wyrażona przez niego opinia nie była odosobniona, ale stanowiła pewną kontynuację myśli jurysty

114 P. Bonfante, La 'iusta causa' dell'usucapione e il suo rapporto colla ,, bona fides” [w:] idem, Scritti giuridici varii. II: Proprietà e servitù, Milano-Napoli-Palermo-Roma 1918, s. 511.

115 Idem, Le singole 'iusta causae usucapionis' e il titulo putativo [w:] idem, Scritti giuridici varii, II, s. 605 . 
działającego wcześniej. Pozostawiając na chwilę na boku kwestię iusta causa usucapionis, podkreślmy, że konkluzja ta jest chyba najważniejszym dla romanistyki wnioskiem płynącym z zestawienia FV. 1 i D. 18,1,27. Wskazuje bowiem na to, że widoczna wśród rzymskich jurystów tendencja do „pielęgnowania tradycji”"16 może być większa, niż wynika z samej lektury justyniańskich Digestów. Kompilatorzy uznali za stosowne pozostawienie w wypowiedzi Paulusa nawiązania do jednego prawnika - Sabinusa. Tymczasem w oryginale, jeśli jego treść oddaje początek Fragmentów Watykańskich, Paulus toczy dyskusję z pięcioma prawnikami - Sabinusem, Prokulusem, Celsusem, Kasjuszem, Labeonem - a nawet z veteres. Jest to niewątpliwie różnica znaczna.

Wydaje się więc, że w kompilacji justyniańskiej fragment pochodzący od Paulusa został istotnie skrócony. Co dla nas szczególnie ważne, osadzono go wyłącznie w kontekście dobrej wiary, choć pierwotnie tekst zahaczał o zagadnienie titulus usucapionis, jednak wyłącznie z uwagi na zawarte w nim stanowisko Labeona. Jego pogląd, zgodnie z którym brak zgody opiekuna oznaczał nieważność emptio-venditio i tym samym prac causae dla zasiedzenia, nie utrzymał się, jak widać. Przez Paulusa został jeszcze przytoczony, twórcy Digestów nie uznali już tego za stosowne. Dla nas jednak wzmianka o Labeonie w FV. 1 jest istotna. Pokazuje bowiem, że podobnie jak Trebacjusz także ten prawnik widział potrzebę pogłębionej oceny zaistnienia iusta causa usucapionis.

\section{Podsumowanie}

Dla Trebacjusza zasiedzenie mogło nastąpić wtedy, gdy poprzedzał je ważny z punktu widzenia prawa akt, który co do zasady otwierał drogę do przeniesienia własności taki jak emptio-venditio i donatio. Musiał być on ważny i obejmować swoim zakresem przedmiot, który miał stać się następnie własnością nabywcy dzięki posiadaniu, które umożliwiało zasiedzenie. Ciekawe, że okoliczności towarzyszące rozpatrywanym przez tego prawnika sprawom nie były raczej typowe. Jest to istotna obserwacja. Wskazuje bowiem, że Trebacjusz analizował swego rodzaju hard cases w kontekście iusta causa usucapionis. Może to świadczyć o tym, że omawiana przez nas przesłanka zasiedzenia znana była już w czasach Trebacjusza doskonale, w takim stopniu, że prawnicy gotowi byli rozstrzygać przypadki nieoczywiste, nie ograniczając się do odpowiedzi na najprostsze pytania.

Autor pierwszego punktu Fragmentów Watykańskich zdaje się skupiać na ocenie dwóch przesłanek zasiedzenia: dobrej wiary i słusznej przyczyny. Przy czym stanowisko Labeona, zgodnie z którym mamy do czynienia $\mathrm{w}$ opisanym stanie faktycznym z posiadaniem pro possessore, a nie pro emptore, przedstawione jest jako wyjątkowe. W literaturze wskazuje się, że z posiadaniem pro possessore wiązał Labeon brak możliwości zasiedzenia rzeczy, wobec czego analiza przesłanki dobrej wiary przestawała mieć rację bytu $^{117}$. Ma to sens. To, że autor FV. 1 przytacza kontrowersję dotyczącą podstawy po-

116 T. Giaro, Prawda dogmatyczna..., s. 30.

117 Por. P. Bonfante, Forme primitive ed evoluzione della proprietà romana..., s. 187. 
siadania, nie może być bez znaczenia dla odpowiedzi na pytanie o zasiedzenie, które wydaje się clou tego fragmentu.

Jak już zauważyliśmy, w kwestii dobrej wiary w FV. 1 przywołano poglądy prawników, których można zaliczyć do Sabinianów. Na temat podstawy posiadania stanowisko zajęli Prokulianie. Można więc z jednej strony wysnuć wniosek, że Sabinianie, tak jak wcześniej veteres, skupili swoją uwagę na kwestii istnienia bądź nie dobrej wiary ${ }^{118}$, podczas gdy Prokulianie w pierwszej kolejności pochylili się nad problemem podstawy posiadania. Z drugiej Paulus mógł przywołać w tej kwestii poglądy następców Labeona po to, aby tym mocniej zakwestionować jego stanowisko, z którym, jak wiemy, się nie zgadzał i które nie zostało już przedstawione w Digestach.

Wiemy jednak, że Trebacjusz nie był jedynym jurystą, który rozważał przesłankę słusznej przyczyny zasiedzenia w czasach, w których żył. Stanowisko Labeona, choć szczęśliwie przechowane do naszych czasów przez Fragmenty Watykańskie, potwierdza obserwacje poczynione na gruncie źródeł przywołujących poglądy jego politycznego przeciwnika. Rozróżnienie na possessio pro possessore i possessio pro emptore musiało już wówczas być znane. Przy czym possessio pro possessore nie pozwalała na zasiedzenie rzeczy, w odróżnieniu od possessio pro emptore (w którego wypadku konieczna była dodatkowo dobra wiara). W czasach Labeona i Trebacjusza iusta causa usucapionis miała więc znaczenie i była poddana szerszej dyskusji. Co istotne, ocena tego, czy mieliśmy do czynienia z possessio pro emptore, odbywała się na podstawie analizy, czy ważna była czynność prawna (emptio-venditio) zawarta w określonej sytuacji.

W okres pryncypatu weszło więc już prawo rzymskie ze zrozumiałą dla prawników przesłanką słusznej przyczyny zasiedzenia. Rozumieli ją ściśle jako akt prawny, którego konsekwencją miało być przeniesienie własności rzeczy (w drodze znanych wówczas czynności, takich jak traditio, mancipatio, in iure cessio). Co ciekawe, już wówczas instytucja zasiedzenia musiała być na tyle rozwinięta, że prawnicy nie skupiali się na podstawowych problemach z nią związanych, ale rozstrzygali hard cases.

\section{Bibliografia}

\section{Źródła}

Ciceor's Letters to Atticus, ed. D.R. Shackleton Bailey, t. I, Cambridge 1965.

Codicis vaticani $n .5766$ in quo insunt iuris anteiustiniani fragmenta quae dicuntur vaticana. Exemplum addita transcriptione notisque criticis, ed. Th. Mommsen, Berolini 1860.

Digesta. Corpus Iuris Civilis, vol. I, ed. Th. Mommsen, P. Kriiger, Berolini 1954.

Gai institutiones iuris civilis rom. Secundum Guilelmi Studemund cod. Ver. Collationem edid. mend. Notisque illustravit. Appositis Iustiniani Institutionibus, iis quidem ex recensione Pauli Krueger fere repetitis, ad locos deperditos lumina adiecit ex Epitome Gaiana, Ulpiani Fragmentis allisque B.J. Polenaar, Lugduni Batavorum, 1876.

118 Por. M. Kaser, Eigentum und Besitz im Älteren Römischen Recht, s. 360; H. Hausmaninger, Die bona Fides..., s. 13-27; zob. też: D. 18,1,27. 
Gai institutiones ad codicis veronensis apographum studemundianum in usum scholarum, red.

P. Krueger, G. Studemund, Berolini 1877.

Gai institutionum commentarii IV mit philologischem kommentar herausbeben von M. David und H.L.W. Nelson, Leiden 1960.

Gai instutitutiones codicis veronensis apographum ad Goescheni Hollwegi Bluhmii schedas conpositum scripsit lapidibusque exceptam scripturam publicavit Eduardus Böcking, Lipsiae 1866.

Palingenesia iuris civilis iuris consultorum reliquiae qnae iustiniani Digestis continentur ceteraque iuris prudentiae civilis fragmenta minora secundum ductores et libras, ed. O. Lenel, vol. I-II, Lipsiae 1889.

Iuris civilis anteiustinianei vaticana fragmento e codice rescripto ab Angelo Maio edita recognovit, commentario tum critic tum exegetico nec non quadruplici appendice instruxit Alex. Aug. de Buchholtz, doctor iuris utriusque, Borussia 1828.

Iuris romani anteiustininianei fragmenta vaticana e codice palimpsesto, ed. A. Maius, RomaeBerolini 1824.

Kaser M., Fragmentum Vaticanum 1, „Labeo” 1961, t. 7.

Locorum ex iure Romano anteiustiniano ab incerto scriptore collectorum fragmenta quae dicuntur vaticana, ed. A. Maius, rec. A. Bethman-Hollweg, Bonnae 1833.

\section{Opracowania}

Abramenko A., Eine übersehene Stellungnahme des Trebatius zum Eigentumerwerb am partus ancillae furtivae. Zu Pomp. D. 41,10,4 pr. und Ulp. D. 6,2,11,2, ZRG RA, 1997, t. 114.

Albanese B., Le situazioni possessorie nel diritto privato romano, Palermo 1985.

Albanese B., Usus auctoritas fundi in XII Tab. 6,3 secondo le testimonianze di Cicerone, AUPA, 1998, t. $45 / 1$.

Albertario E., Studi di diritto romano, vol. 2: Cose-diritti reali-possesso, Milano 1941.

Albertario E., Studi di diritto romano, vol. V, Milano 1937.

Andrés Santos F.J., En torno al origen y fundamento de la prohibición de donaciones entre cónyuges: una reconsidereción critica, „Bullettino dell'Istituto di Diritto Romano 'Vittorio Scialoja', 3 serie", 2000-2001, t. 42-43.

Ankum H., Pool E., The Development of Roman Double Ownership [w:] New Perspective in the Roman Law of Property, red. P. Birks, Oxford 1999.

Bauer K., Die rutiliana constitutio des Julian, TR, t. 1, 1986, passim.

Bělovský P., Usucapio of Stolen Things and Slave Children, „Revue internationale des sciences sociales" 2002, t. 49.

Benferhat Y., Cicero's Law. Rethinking Roman Law of the Late Republic, red. P. du Plessis, Edinburgh 2016.

Berger A., Encyclopedic Dictionary of Roman Law, Philadelphia 1980.

Biondi B., Istituzioni di diritto romano, wyd. 3, Milano 1956.

Bonfante P., Corso di diritto romano, t. I, Roma 1925, http://www.teoriaestoriadeldirittoprivato. com/index.php?com=statics\&option $=$ index \&cID=207 (dostęp: 01.05.2018).

Bonfante P., Essenza della 'bona fides'e suo rapporto colla teorica dell'errore [w:] idem, Scritti qiurdici II Proprieta e sarviu, Milano Napoli -Palermo Roma 1918.

Bonfante P., Forme primitive ed evoluzione della proprietà romana (,,Res mancipi” e „res nec mancipi”) [w:] Scritti giuridici varii, t. 2: Proprietà e servitù, Milano-Napoli-Palermo-Roma 1918.

Bonfante P., La 'iusta causa' dell'usucapione e il suo rapporto colla ,,bona fides” [w:] idem, Scritti giuridici varii. II: Proprietà e servitù, Milano-Napoli-Palermo-Roma 1918.

Artykuły - Articles 
Bonfante P., Le singole 'iusta causae usucapionis'e il titulo putativo [w:] Scritti giuridici varii, t. 2: Proprietà e servitù, Milano-Napoli-Palermo-Roma 1918.

Bonfante P., Scritti giuridici varii, [w:] P. Bonfante, II Proprietà e servitù, Milano-Napoli-Palermo-Roma 1918.

Böhr R., Das Verbot der Eigenmächtigen Besitzumwandlung im Römischen Privatrecht. Ein Beitrag zur Rechtshistorischen Spruchregelforschung, München-Leipzig 2015.

Buchholtz A.A., Excursus I. De Fontibus Vaticanorum Fragmentorum [w:] Iuris civilis anteiustinianei vaticana fragmento e codice rescripto ab Angelo Maio edita recognovit, commentario tum critic tum exegetico nec non quadruplici appendice instruxit Alex. Aug. de Buchholtz, doctor iuris utriusque, Borussia 1828.

Casiono-Mora J., Auctoritas rerum decemviralis, RIDA, 3 Série, 2003, t. 50.

Chiazzese L., Confronti testuali. Contributo alla dottrina della interpolazioni giustinianee, AUPA, 1931, t. 16.

Dajczak W., Giaro T., Longchamps de Bérier F., Prawo rzymskie. U podstaw prawa prywatnego, Warszawa 2009.

David M., Nelson H.L.W., Gai institutionum commentarii IV mit philohogischem kommentar herausgegeben, Studia Gaiana III, Leiden 1960.

de Filippi M., Fragmenta Vaticana. Storia di un testo normativo, Bari 1998.

Diósdi G., Ownership in Ancient and Preclassical Roman Law, Budapest 1970.

Fuenteseca P., La auctoritas como principio constutucional romano [w:] Libro homenaje al profesor Manuel Albaladejo Garcia, t. I, red. J.M. González Porrad, F.P. Méndzez González, Murcia 2004.

Giaro T., Diritto come prassi. Vicende del discorso giurisprudenziale [w:] Fides, humanitas, ius. Studi in onore di Luigi La bruna, t. IV, Napoli 2007.

Giaro T., Prawda dogmatycza i „ponadczasowość” jurysprudencji rzymskiej, CPH, 1988, t. 40, z. 1.

Giaro T., Własność w Rzymie republikańskim, CPH, 1973, t. 25, z. 2.

Guarino A., L'esegesi delle fonti del diritto romano, Napoli 1968.

Guarino A., Pagine di diritto romano, t. II, Napoli 1993.

Hausmaninger H., Die bona fides des ersitzungsbesitzers im klassischen römischen recht, WienMünchen 1964.

Hausmaninger H., Nemo sibi ipse causam possessionis mutare potest-eine Regel der veteres in der Diskussion der Klassiker [w:] Aktuelle Fragen aus modern Recht und Rechtsgeschichte. Gedächtnisschrift für Rudolf Schmidt, red. E. Seidl, Berlin 1966.

Herrmann-Otto E., Ex ancilla natus, Sttuttgart 1994.

Johnston D., Roman Law in Context, Cambridge 2007.

Jolowicz H.F., Historical Introduction to the Study of Roman Law, Cambridge 1932.

Kaser M., Altrömisches Eigentum und ,, usucapio”, ZRG RA, 1998, t. 105.

Kaser M., Eigentum und Besitz. Im älteren Roömischen Recht, Köln-Graz 1956.

Kaser M., Partus ancillae, ZRG RA, 1958, t. 88.

Katančević A., Bопа fides као услов узукапије у класичном римском праву, Belgrad 2012.

Kozubski W., Opieka nad kobietami w prawie rzymskim, Kraków 1922.

Lauria M., ... usus auctoritas fundi biennium est... [w:] De iustitia et iure: Festgabe für Ulrich von Lübtow zum 80. Geburstag, red. M. Harder, G. Thielmann, Berlin 1980.

Levy E., Westen und Osten in der nachklassichen Entwicklung des römischen Rechts, ZRG RA, 1929, t. 49.

Levy E., Rabel E., Index Interpolationum quae in Iustiniani digesits inesse dicuntur, ad D. 41,4,2,7.

Litewski W., Jurysprudencja rzymska, Kraków 2000.

Maccormack G., Nemo sibi ipse causam possessionis mutare potest, BIDR, 3 serie, 1972, t. 14.

Manzo A., Magnum munus de iure respondendi substinebat. Studi su Publio Rutilio Fufo, Milano 2016. 
Mayer-Maly Th., Studien zu Frühgeschichte der usucapio II, ZRG RA, 1961, t. 78.

Mayer-Maly Th., Das Putatirtitelproblem bei der Usucapio, Köln-Graz 1962.

Nicosia G., Iuris consultorum acutae ineptiae [w:] Studi di onore di Remo Martini, II, Milano 2009.

Nicotri M.T., De dote quantitate. A proposito di Cels. D. 23.3.60 e 32.43, „Teoria e Storia del Diritto Privato" 2011, t. 4.

Pernice A., Labeo. Römisches Privatrecht in Ersten Jahrhundert der Kaiserzeit, Teil C, Band 2 Abteilund 1 in 2. Auflage 7. Buch: Dolus malus und bona fides, 1895, reprint. Allen 1963.

Pool E., Significati diversi di causa in tema di possessio e di usucapio. Interpretazioni di qualche testo chiave, Parte I, AUPA, 2016, t. 59.

Riccobono S., Sul Fr. 4 Pr. D. Pro Suo e la vesione greca riportata da Armenopulo [w:] S. Riccobono, Stritti di diritto romano, t. I, Palermo 1957.

Robinson O.F., The Sources of Roman Law: Problems and Methods for Ancient Historians, London-New York 2006.

Roby H.J., An Introduction to the Study of Justinians's Digest Containing an Account of Its Composition and of the Jurists Used of Referred to Therein Together with a Full Commentary on the Title (De Usufructu), Cambridge 1884.

Roby H.J., Roman Private Law in the Times of Cicero and of the Antonines, t. I, New Jersey 2000.

Savigny F.K., Das Rechts des Besitzes: eine civilistische Abhandlung, Wien 1865.

Schrage E.J.H., res habilis, titulus, fides, possessio, tempus. A medieval mnemonic hexameter? [w:] F. Sturm, P. Thomas, J. Otto, Liber Amicorum Guido Tsuno, Frankfurt am Main 2013.

Sirks A.J.B., An Aspect of Archaic Roman Law: Auctoritas Tutoris [w:] The Law's Beginnings, red. F.J.M. Feldbrugge, Leiden-Boston 2003.

Solazzi S., Quod falso tutore auctore gestum esse dicatur [w:] S. Solazzi, Scritti di diritto romano, t. II, Napoli 1957.

Sorka K., Interpolacje „Digestów” justyniańskich. Rys historyczno-metodologiczny, „Forum Prawnicze" 2017, nr 5.

Stein P., The Two Schools of Jurists in the Early Roman Principate, „Cambridge Law Journal” 1972, t. 31.

Voci P., Modi di acquisto della proprierà, Milano 1952.

Watson A., Roman Law and Comparative Law, Georgia 1991.

Watson A., Rome of the XII Tables. Persons and Property, New Jersey 1975.

Watson A., The Law of Persons in the Later Roman Republic, Oxford 1984.

Watson A., The Law of Property in the Later Roman Republic, Oxford 1968.

Wesenberg G., Fr. 18 Pr. D. 41, 2 Ein Beitrag zur Lehre vom Constitutum Possessorium [w:] Studi in memoria di Emilio Albertario, t. II, Milano 1953.

Wieacker F., Textstufen klassischer Juristen in the Roman Law of Property, ed. P. Birles, Oxford 1999.

Winkel L., Usucapio pro suo and the Classification of the causae usucapionis by the Roman Jurists [w:] New Perspectives...

Zabłocka M., Zanikanie instytucji tutela mulierum w prawie ryzymskim „Prawo Kanoniczne” 1987.

Zimmermann R., The Law of Obligations. Roman Foundations of the Civilian Traditions, Cape Town-Wetton-Johannesburg 1992. 